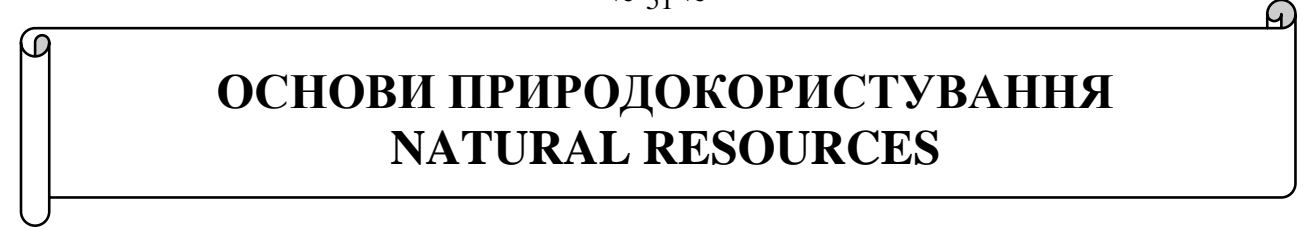

УДК 502/504 : 349.6

Victoria M. Mikheenko, $\mathrm{PhD}$, Associate Professor

ORCID ID 0000-0001-7685-2507e-mail: v.m.mikheenko@donnaba.edu.ua

Ivan G. Hevlych, $\mathrm{PhD}$, Associate Professor

ORCID ID 0000-0003-2282-0512 e-mail: i.g.gevlich@donnaba.edu.ua

Taras I. Hevlych, student

ORCID ID 0000-0003-3387-1657e-mail: t.gevlich@donnaba.edu.ua

Donbas National Academy of Civil Engineering and Architecture, Kramatorsk, Ukraine

\title{
REGULATION OF FOOD WASTE MANAGEMENT IN UKRAINE AND ABROAD
}

\begin{abstract}
In the world in general and in Ukraine in particular, there is a catastrophic environmental situation with food waste. The solution to the problem of waste accumulation, the organization of quality control of compliance with legislation in their treatment, the formation of environmental awareness of the population is hampered by the lack of unanimity in defining the essence of waste, industrial waste, waste in the regulatory framework and among scientists. The aim of the work is to study the essence of the definition of food waste in domestic and foreign scientific discussions and regulations in terms of improving the regulation of their treatment in Ukraine. Scientific discussion of domestic and foreign authors on the concept of waste, in particular food, as well as their regulations demonstrate a wide variety of not only definitions but also approaches. This takes into account the legal basis for waste operations, their physical condition and properties, environmental and economic characteristics, the criterion of goal setting, accounting approach and so on. The analysis of the existing classifications of waste stated the absence of a separate category of food waste both in the works of Ukrainian scientists and in domestic regulations, while foreign authors are actively researching this category. According to the results of the study, it is proposed to introduce into the domestic regulatory framework the term "loss of food and food waste" commonly used abroad with the following definition: products (substances) as edible parts of plants and animals produced or collected for human consumption but ultimately not consumed. Critical analysis of domestic environmental legislation in comparison with European allowed to propose the implementation of the Waste Framework Directive, as well as the formation of a hierarchy of waste management priorities: prevention, preparation for reuse, recycling, other types of disposal, elimination as Ukraine's European integration. Areas of further research will be the study of food waste disposal technologies of the modern city.
\end{abstract}

Key words: food loss; food waste; environmental legislation; implementation

В.М. Міхєєнко, І.Г. Гевлич, Т.І. Гевлич, 2021

ISSN: 2411-4049. Екологічна безпека та природокористування, № 3 (39), 2021 


\title{
В.М. Міхсєнко, І.Г. Гевлич, Т.І. Гевлич
}

Донбаська національна академія будівництва і архітектури, м. Краматорськ, Україна

\section{РЕГУЛЮВАННЯ ПОВОДЖЕННЯ 3 ХАРЧОВИМИ ВІДХОДАМИ В УКРАЇНІ ТА ЗА КОРДОНОМ}

\begin{abstract}
Анотація. У світі в иілому та Україні зокрема склалася катастрофічна екологічна ситуація з харчовими відходами. Виріменню проблеми накопичення відходів, організаиії якісного контролю дотримання законодавства $у$ поводженні з ними, формуванню екологічної свідомості населення заважсє відсутність одностайності щодо визначення сутності понять відходів, промислових відходів, відходів виробництва у нормативній базі та серед науковиів. Метою роботи є дослідження сутності дефініиії харчових відходів у вітчизняній та закордонній науковій дискусії та нормативних документах $з$ точки зору удосконалення регулювання поводження з ними в Україні. Наукова дискусія вітчизняних та закордонних авторів щодо поняття відходів, зокрема харчових, як і нормативні їх регламенти демонструють широке розмаїття не тільки визначень, а й підходів. При иьому приймаються до уваги правові засади здійснення операиій з відходами, їх фізичний стан і властивості, екологічні та економічні ознаки, критерій иілепокладання, обліковий підхід тощо. Аналіз існуючих класифікачій відходів констатував відсутність окремої категорії харчових відходів як у роботах українських науковців, так $i$ у вітчизняних нормативних регламентах у той час, як закордонні автори активно досліджують дану категорію. За результатами дослідження запропоновано введення у вітчизняну нормативну базу загальновживаного за кордоном терміну «втрата продовольства та харчові відходи» з таким визначенням: продукти (речовини) як їстівні частини рослин і тварин, які виробляються або збираються для споживання людиною, але в кінцевому рахунку не споживаються. Критичний аналіз вітчизняного екологічного законодавства у порівнянні із європейським дозволив запропонувати імплементацію Рамкової директиви про відходи, а також формування ієрархї̈ пріоритетів поводження з відходами: запобігання, підготовка до повторного використання, переробка, інший тип утилізації, ліквідація, як напрям євроінтеграиії Украӥни. Напрямами подальшого дослідження виступатиме вивчення технологій утилізачії харчових відходів сучасного міста.
\end{abstract}

Ключові слова: втрата продовольства; харчові відходи; екологічне законодавство; імплементація

DOI: https://doi.org/10.32347/2411-4049.2021.3.51-68

\section{Вступ}

Наша країна, стикаючись із проблемами утворення та утилізації харчових відходів, не поодинока. Незважаючи на локальні проблеми із продовольством, у світі склалася катастрофічна ситуація з даним видом відходів, розмір яких до 2030 р., за даними Boston Consulting Group, сягатиме 2,1 млрд тонн. На наш погляд, вирішенню екологічних проблем, пов'язаних із накопиченням відходів, організації якісного контролю дотримання законодавства у поводженні з ними, а також формуванню екологічної свідомості населення заважає відсутність одностайності щодо визначення сутності понять відходів, промислових відходів, відходів виробництва у нормативній базі та серед науковців. 
Метою роботи $є$ дослідження сутності дефініції харчових відходів у вітчизняній та закордонній науковій дискусії та нормативних документах з точки зору удосконалення регулювання поводження з ними в Україні.

\section{Виклад результатів дослідження}

Наукова дискусія вітчизняних та закордонних авторів щодо поняття відходів, зокрема харчових, як і нормативні їх регламенти демонструють широке розмаїття не тільки визначень, а й підходів.

Н.О. Корнякова [1] характеризує відходи як полівидове поняття, що може розглядатися з огляду на правові засади здійснення операцій з ними, фізичний стан і властивості, екологічні та економічні ознаки тощо. А.Д. Трусов i А.Н. Захаров [2] стверджують, що поняття відходів змінюється iз впровадженням досягнень науково-технічного прогресу, B.I. Кержаков та O.M. Дериколенко ототожнюють відходи зі вторинними матеріальними ресурсами [3], а Н.І. Пилипів вважає, що сутність досліджуваного поняття змінюється залежно від специфіки діяльності підприємства, на якому відходи утворюються [4].

Визначення основних дефініцій щодо відходів у вітчизняній нормативній базі, а саме, у Законах України «Про відходи», «Про альтернативні види рідкого та газового палива», Державному Класифікаторі відходів, ДСТУ 2195-99 «Охорона природи. Поводження 3 відходами» та Наказі Держкоммістобудування «Про затвердження Методики обстеження й паспортизації гідротехнічних споруд» [5-9] представлені у табл. 1.

Як видно 3 табл. 1, основним визначальним критерієм виступає цілепокладання: відходи розглядаються як результат діяльності та мають своє призначення. Закон «Про відходи», Класифікатор відходів ДК 005-96, ДСТУ 2195-99 акцентують увагу на намірах або зобов'язаннях виробника відходів здійснити певні дії з відходами, але закон, як не дивно, не наголошує на екологічному аспекті небезпеки відходів для навколишнього середовища та здоров'я людей, а Класифікатор це робить. В.В. Пікінер у роботі [10] обгрунтовує важливість врахування екологічної складової при визначенні відходів як найбільш соціально спрямованої характеристики.

В. Пендак та О. Паславська на основі аналізу правового поняття відходів пропонують такі основні ознаки відходів:

- утворення в результаті людської діяльності, природних та техногенних катастроф;

- неможливість подальшого використання за місцем утворення чи виявлення;

- наявність власника, тобто належність відповідним особам (юридичним, фізичним, територіальним громадам, державі);

- наявність обов'язків власника позбутися відходів шляхом їх утилізації чи видалення;

- подвійна природа відходів: забруднююча речовина, що створює небезпеку навколишньому природному середовищу, та ресурс як джерело переробки [11]. 
Саме $з$ урахуванням останньої ознаки В.В. Пікінер акцентує увагу на майбутніх економічних вигодах, що можуть бути отримані підприємствами, на яких утворюються певні види відходів, внаслідок:

- реалізації відходів іншим суб'єктам господарювання, які їх будуть використовувати як вторинну сировину або альтернативний вид палива;

- використання відходів для власних потреб (за умови забезпечення належних технологічних умов);

- державного стимулювання впровадження маловідходних та безвідходних технологій.

Таблиця 1 - Визначення поняття відходів у вітчизняній нормативній базі

\begin{tabular}{|c|c|}
\hline Нормативний документ & Сутність поняття \\
\hline $\begin{array}{l}\text { Закон України «Про } \\
\text { відходи» }\end{array}$ & $\begin{array}{l}\text { будь-які речовини, матеріали і предмети, що утворилися у } \\
\text { процесі виробництва чи споживання, а також товари } \\
\text { (продукція), що повністю або частково втратили свої } \\
\text { споживчі властивості і не мають подальшого } \\
\text { використання за місцем їх утворення чи виявлення і від } \\
\text { яких їх власник позбувається, має намір або повинен } \\
\text { позбутися шляхом утилізації чи видалення }\end{array}$ \\
\hline $\begin{array}{lrr}\text { Закон України } & \text { «Про } \\
\text { альтернативні } & \text { види } \\
\text { рідкого та газового } \\
\text { палива» }\end{array}$ & $\begin{array}{l}\text { шлаки та відходи промисловості, сільського господарства, } \\
\text { комунально-побутових та інших підприємств, які можуть } \\
\text { бути джерелом або сировиною для видобутку чи } \\
\text { виробництва альтернативних видів палива }\end{array}$ \\
\hline $\begin{array}{l}\text { Класифікатор } \\
\text { ДК відходів } 005\end{array}$ & $\begin{array}{l}\text { будь-які речовини та предмети, утворювані у процесі } \\
\text { виробництва та життєдіяльності людини, внаслідок } \\
\text { техногенних чи природних катастроф, що не мають свого } \\
\text { подальшого призначення за місцем утворення і підлягають } \\
\text { видаленню чи переробці } з \text { метою забезпечення захисту } \\
\text { навколишнього середовища і здоров’я людей або з метою } \\
\text { повторного їх залучення у господарську діяльність як } \\
\text { матеріально-сировинних і енергетичних ресурсів, а також } \\
\text { послуги, пов'язані з відходами }\end{array}$ \\
\hline $\begin{array}{lr}\text { ДСТУ } & 2195-99 \\
\text { «Охорона } & \text { природи. } \\
\text { Поводження } & 3 \\
\text { відходами. } & \text { Технічний } \\
\text { паспорт відходу» } \\
\end{array}$ & $\begin{array}{l}\text { речовини, матеріали і предмети, які утворюються в } \\
\text { процесі людської діяльності, не мають подальшого } \\
\text { використання за місцем утворення чи виявлення та яких } \\
\text { їхній власник позбувається, має намір або повинен } \\
\text { позбутися шляхом утилізації чи видалення }\end{array}$ \\
\hline $\begin{array}{l}\text { Методика обстеження й } \\
\text { паспортизації } \\
\text { гідротехнічних споруд } \\
\text { систем гідравлічного } \\
\text { вилучення } \\
\text { складування } \\
\text { промислових відходів }\end{array}$ & $\begin{array}{l}\text { Непридатні для виробництва даної продукції види } \\
\text { сировини, їі залишки, що не вживаються, або речовини, які } \\
\text { виникають в результаті технологічних процесів, які не } \\
\text { підлягають утилізації у даному виробництві }\end{array}$ \\
\hline
\end{tabular}

3 урахуванням вищевикладеного дослідник пропонує виокремлювати обліковий підхід до визначення відходів на основі таких тверджень:

- створення відходів в результаті різних господарських процесів звичайної діяльності підприємств та внаслідок надзвичайних подій; 
- врахування придатності чи непридатності їх подальшого використання при певних умовах організаційно-технічного забезпечення підприємства;

- зазначення правових аспектів поводження 3 відходами (законодавчі вимоги позбутися відходів, передати їх на утилізацію тощо);

- визнання відходів негативним фактором, що має суттєвий вплив на природне середовище, здоров'я і життя людей [10].

Організація ефективного управління відходами і саме розуміння їх сутності неможливе без обгрунтованої класифікації. Класифікатор ДК 005-96 пропонує такий поділ відходів на групи за різновидами:

1) залишки сировини, матеріалів, напівфабрикатів тощо, які утворені в процесі виробництва продукції або виконання робіт і втратили цілком або частково вихідні споживчі властивості (відходи виробництвва);

2) розкривні і супутні гірничі породи, що видобуваються у процесі розроблення родовищ корисних копалин;

3) залишкові продукти збагачення та інших видів первинної обробки сировини (шлам, пил, відсіви тощо);

4) новоутворені речовини та їх суміші, утворені в термічних, хімічних та інших процесах і які не є метою даного виробництва (шлак, зола, кубові залишки, інші тверді та пастоподібні утворення, а також рідини та аерозолі);

5) залишкові продукти сільськогосподарського виробництва (у т. ч. тваринництва), лісівництва і лісозаготівель;

6) бракована, некондиційна продукція усіх видів економічної діяльності або продукція, що забруднена небезпечними речовинами і не придатна до використання;

7) неідентифікована продукція, застосування (експлуатація) або вживання якої може спричинити непередбачені наслідки, у т. ч. мінеральні добрива, отрутохімікати, інші речовини;

8) зіпсовані (пошкоджені) і неремонтоздатні чи відпрацьовані, фізично або морально зношені вироби та матеріали, які втратили свої споживчі властивості (відходи спожсивання);

9) залишки продуктів харчування, побутових речей, пакувальних матеріалів тощо (побутові відходи);

10) осади очисних промислових споруд, споруд комунальних та інших служб;

11) залишки від медичного та ветеринарного обслуговування, медикобіологічної та хіміко-фармацевтичної промисловості, аптечної справи;

12) залишкові продукти усіх інших видів діяльності підприємств, установ, організацій і населення;

13) матеріальні об’єкти та субстанції, активність радіонуклідів або радіоактивне забруднення яких перевищує межі, встановлені чинними нормами, за умови, що використання цих об'єктів та субстанцій не передбачається (радіоактивні відходи).

Разом з тим у Класифікаторі використовуються додаткові ознаки поділу відходів:

1) за видами економічної діяльності суб'єкта господарювання, де утворилися доходи;

2) за фазою процесу, на якій утворилися доходи;

3) за елементом процесу, від якого утворилися відходи. 
Крім цього, промислові відходи можна класифікувати за такими ознаками:

- за галузями промисловості (відходи паливної, металургійної, хімічної та інших галузей);

- за конкретними виробництвами (відходи сіркокислотного, содового, фосфорокислотного та інших виробництв);

- за агрегатним станом (тверді, рідкі, газоподібні);

- за горінням (горючі та негорючі);

- за методами переробки;

- за можливостями переробки (вторинні матеріальні ресурси (ВМР), що переробляються або плануються надалі перероблятися, і відходи, що на даному етапі розвитку економіки переробляти недоцільно);

- за рівнем небезпеки (надзвичайно небезпечні, високонебезпечні, помірнонебезпечні, малонебезпечні).

Харчові відходи, які є предметом дослідження у даній роботі, є побутовими. Загальноприйнята класифікація побутових відходів, озвучена у роботі [12], представлена у табл. 2.

Таблиця 2 - Класифікація побутових відходів

\begin{tabular}{|l|l|}
\hline \multicolumn{1}{|c|}{ Критерії оцінювання } & \multicolumn{1}{|c|}{ Види побутових відходів } \\
\hline Агрегатний стан & $\begin{array}{l}\text { Тверді } \\
\text { Рідкі }\end{array}$ \\
\hline Об’єм & $\begin{array}{l}\text { Великогабаритні } \\
\text { Малогабаритні }\end{array}$ \\
\hline Рівень шкоди для довкілля & Безпечні \\
& Небезпечні \\
\hline Сфера утворення & Сільскогосподарські \\
& Будівельні (ремонтні) \\
& Садово-дачного масиву \\
& Інші \\
\hline Сфера надання послуг & Медична \\
& Пансіонати \\
& Готельно-ресторанний бізнес \\
& Військова \\
\hline Джерело утворення & Житлові будинки: багатоквартирні; приватного \\
& сектору \\
& Будинки адміністративного призначення \\
\hline
\end{tabular}

Як видно з табл. 2, дефініція харчових відходів не виділяється у науковій дискусії. На жаль, поняття харчових відходів відсутне й у вітчизняних нормативних актах. Виходячи з розгляду сутності даної категорії, це харчові продукти, які повністю або частково втратили свої первинні споживчі властивості в процесах їх виробництва, переробки, застосування або зберігання. За джерелом виникнення, це залишки їжі людини та відходи кухонь, пекарень, підприємств харчової промисловості.

Харчові відходи розглядаються як частина побутових відходів і є однією 3 екологічних проблем суспільства споживання, яка широко досліджується зарубіжними науковцями. Так, Б. Ліпінський, К. Хансон, Дж. Ломакс, Л. Кітіноя, Р. Уейт та Т. Сьорчінгер у роботі [13] досліджують втрати продовольства та харчові відходи у глобальному вимірі та пропонують стратегії, 
спрямовані на їх зменшення. У звіті «Global food losses and food waste - Extent, causes and prevention» [14] Продовольча та сільськогосподарська організація OOH (Food and Agriculture Organization, FAO) розкриває втрати, що виникають уздовж харчового ланцюга, оцінює їхню величину та визначає причини втрат харчової продукції та можливі способи їх запобігання. Звіт FAO «Global Initiative on Food Loss and Waste Reduction Food and Agriculture Organization of the United Nations» [15] присвячений стратегіï зменшення обсягів втрати продовольства та харчових відходів у глобалізованому світі.

К. Хансон та П. Мітчел у роботі [16] визначають стратегічні нефінансові мотиватори зменшення обсягів втрат продуктів харчування та відходів. Тімоті Дж. Річардс та Стівен Ф. Гамільтон у роботі [17] досліджують потенціал комерційних однорангових систем мутуалізації (CPMS) або фірм спільної економіки як ринкових платформ обміну надлишковими продуктами харчування i, як наслідок, скорочення харчових відходів. Калліопі Милона, Петрос Марагкудакіс, Ладіслав Міко, Анн-Катрін Бок, Ян Воллгаст, Сандра Калдейра, Франц Улберт у роботі [18] представили результати дослідження харчової політики ЄС до 2050 року $з$ точки зору потенційних майбутніх викликів, зокрема, щодо збільшення виробництва продуктів харчування при використанні меншої кількості ресурсів та зменшення харчових відходів при забезпеченні харчової безпеки. Альберто Зецца, Калоджеро Карлетто, Джон Л. Фідлер, П'єтро Дженнарі та Дін Джолліфф у роботі [19] запропонували методологічні підходи національних опитувань домогосподарств, зокрема, стосовно харчування та поводження $з$ харчовими відходами.

Виходячи 3 аналізу вищезазначених досліджень, відсутності визначення харчових відходів в українських нормативних документах та важливості проблеми харчової безпеки, є доцільним введення у вітчизняну нормативну базу загальновживаного за кордоном терміну «втрата продовольства та харчові відходи» («Food loss and waste»), який визначається таким чином: продукти (речовини) як їстівні частини рослин і тварин, які виробляються або збираються для споживання людиною, але в кінцевому рахунку не споживаються. Втрата продовольства - це непередбачений результат сільськогосподарського процесу або зберігання, транспортування, упаковки продуктів, що спричинив втрату або псування продуктів (аномальне зниження їх якості). Харчові відходи - це продукти, які є якісними та придатними для споживання людиною, але не споживаються до або після аномального зниження їх якості. Харчові відходи $\epsilon$ результатом недбалості або свідомого рішення викинути продукти.

Для розрахунку втрат продовольства та харчових відходів в Україні О. Котикова, М. Бабич та О. Погорєлова пропонують використовувати методику FAO (рис. 1) [20], де A + B + C - D = E - (F + G + H + I) = J = K + L.

Таким чином, за результатами дослідження сутності поняття відходів та харчових відходів у національному законодавстві та науковій дискусії констатована відсутність визначеного поняття харчових відходів в українському законодавстві та неоднозначність трактування дефініції «відходи» у різних нормативних документах та дослідженнях науковців. Це утруднює ефективне управління відходами та потребує корекції на національному рівні. Запропоновано введення до вжитку поняття «втрата продовольства та харчові відходи» («Food loss and waste»), яке широко 
використовується за кордоном, зокрема, Продовольчою та сільськогосподарською організацією ООН (FAO).

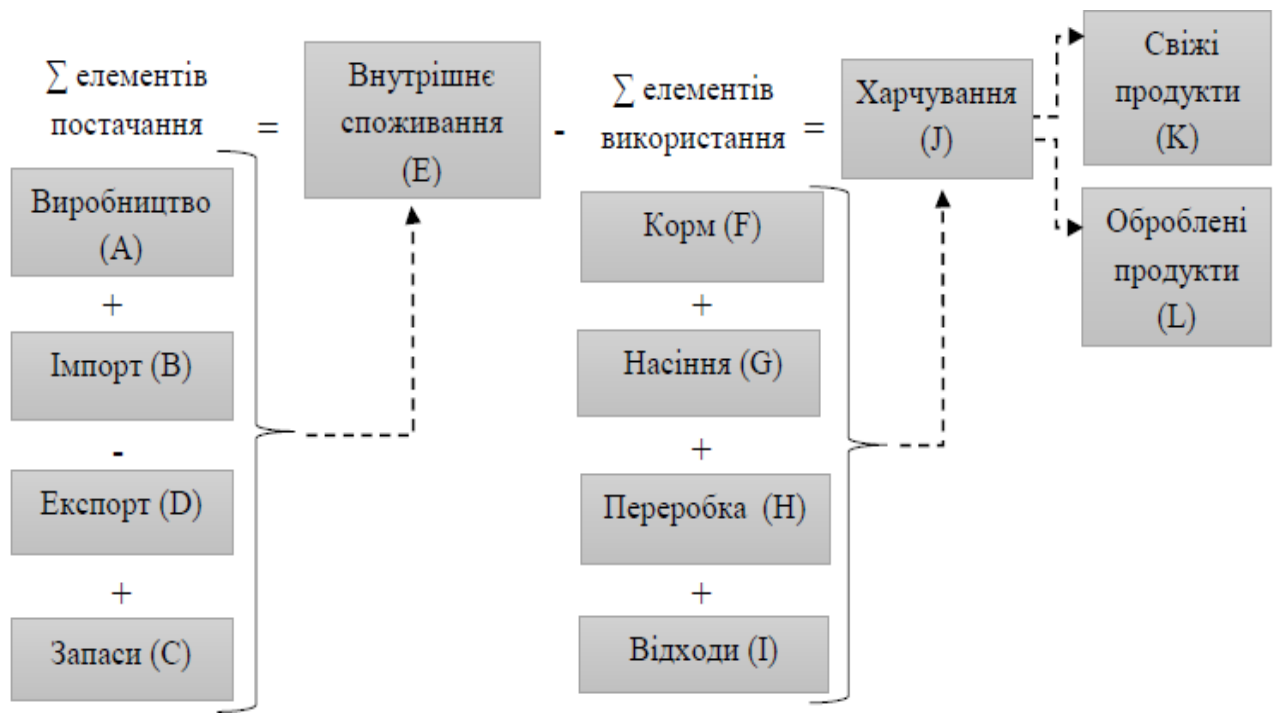

Рис. 1 - Методика розрахунку втрат продовольства та харчових відходів за ФАО

В Україні поводження 3 відходами регламентовано законами «Про відходи», «Про охорону навколишнього природного середовища», «Про забезпечення санітарного та епідемічного благополуччя населення», «Про поводження з радіоактивними відходами», «Про металобрухт», «Про житловокомунальні послуги», «Про хімічні джерела струму», «Про ветеринарну медицину», «Про вилучення з обігу, переробку, утилізацію, знищення або подальше використання неякісної та небезпечної продукції», Кодексом України про надра, іншими нормативно-правовими актами [5, 21-29].

Основними принципами державної політики у сфері поводження 3 відходами є:

- пріоритетний захист навколишнього природного середовища та здоров’я людини від негативного впливу відходів;

- забезпечення ощадливого використання матеріально-сировинних та енергетичних ресурсів;

- науково обгрунтоване узгодження екологічних, економічних та соціальних інтересів суспільства щодо утворення та використання відходів 3 метою забезпечення його сталого розвитку.

Основні завдання та напрями державної політики щодо відходів в Україні представлені у табл. 3.

У сфері поводження 3 відходами міністерствами, іншими центральними органами виконавчої влади, підприємствами, установами та організаціями за погодженням із уповноваженими органами виконавчої влади з питань охорони навколишнього природного середовища встановлюються граничні показники утворення відходів у технологічних процесах, питомі показники утворення відходів, використання та втрат сировини у технологічних процесах, інші нормативи, передбачені законодавством. 
Таблиця 3 - Завдання та напрями державної політики щодо відходів в Україні

\begin{tabular}{|c|c|}
\hline Завдання & Напрями \\
\hline $\begin{array}{l}\text { - визначення основних } \\
\text { принципів державної політики у } \\
\text { сфері поводження з відходами; } \\
\text { - правове регулювання відносин } \\
\text { щодо діяльності у сфері } \\
\text { поводження з відходами; } \\
\text { - визначення основних умов, } \\
\text { вимог і правил щодо екологічно } \\
\text { безпечного поводження } \\
\text { відходами, а також системи } \\
\text { заходів, пов’язаних } \\
\text { організаційно-економічним } \\
\text { стимулюванням } \\
\text { ресурсозбереження; } \\
\text { - забезпечення мінімального } \\
\text { утворення відходів, розширення } \\
\text { їх використання у господарській } \\
\text { діяльності, запобігання } \\
\text { шкідливому впливу відходів на } \\
\text { навколишнє природне } \\
\text { середовище та здоров’я людини }\end{array}$ & 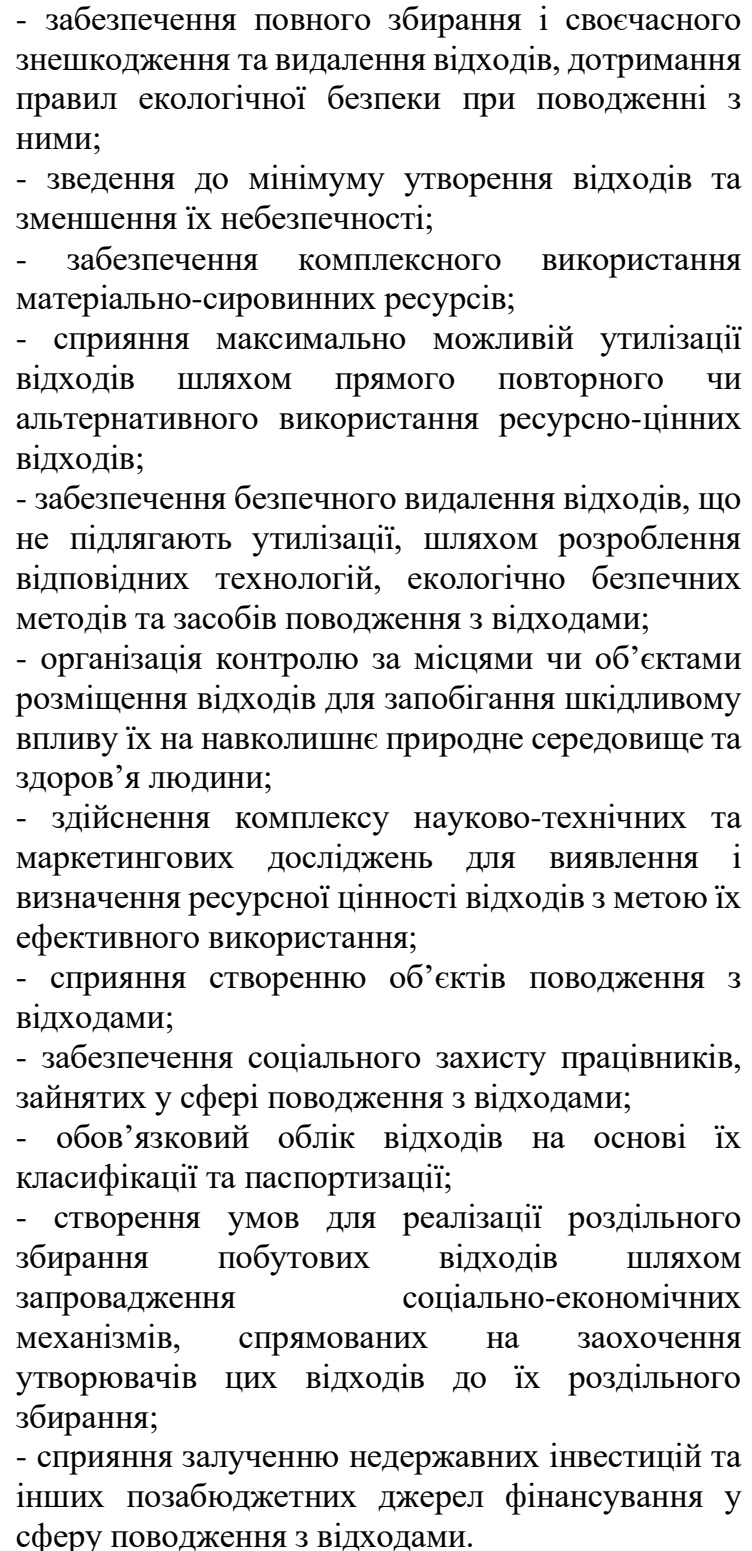 \\
\hline
\end{tabular}

Закон «Про відходи» [5] встановлює права та обов'язки юридичних та фізичних осіб щодо поводження із відходами. Законодавство також вимагає розробки заходів і вимог щодо запобігання або зменшення утворення відходів та екологічно безпечного поводження з ними, зокрема:

- розроблення та впровадження науково обгрунтованих нормативів утворення відходів на одиницю продукції (сировини та енергії), виконання робіт і надання послуг, що регламентують їх кількісний та якісний склад, відповідно до передових технологічних досягнень; 
- періодичний перегляд встановлених нормативів утворення відходів, спрямований на зменшення їх обсягів, з урахуванням передового вітчизняного і зарубіжного досвіду та економічних можливостей;

- розроблення та впровадження системи поводження 3 пакувальними матеріалами і тарою; системи збирання, видалення, знешкодження та утилізації відпрацьованих мастил (олив); системи збирання, заготівлі та утилізації зношених шин, резинотехнічних виробів та відходів резинотехнічного виробництва; системи заготівлі та утилізації непридатних до використання транспортних засобів; системи збирання та утилізації електричного та електронного обладнання; системи збирання, видалення, знешкодження, утилізації відходів, що утворюються у процесі медичного обслуговування, ветеринарної практики, пов'язаних з ними дослідних робіт;

- розроблення загальних вимог щодо поводження 3 побутовими відходами;

- розроблення системи інформаційного, науково-методичного забезпечення виробників відходів відомостями про технологічні та інші можливості зменшення обсягів утворення та утилізації відходів.

3 метою обмеження та запобігання негативному впливу відходів на навколишнє природне середовище та здоров'я людини забороняється:

- провадити будь-яку господарську діяльність, пов'язану з утворенням відходів, без одержання від місцевих органів виконавчої влади дозволу на здійснення операцій у сфері поводження з відходами відповідно до вимог цього Закону;

- використовувати результати наукових досліджень, впроваджувати в практику винаходи, застосовувати нову техніку, імпортне устаткування, технології та системи, якщо вони не передбачають запобігання чи мінімізацію обсягів утворення відходів на всіх стадіях технологічного процесу, їх утилізацію та безпечне видалення;

- визначати місця розміщення підприємств, установок, полігонів, комплексів, сховищ та інших об'єктів поводження з відходами, проектувати та будувати регіональні і міжрегіональні комплекси оброблення, знешкодження, утилізації та видалення відходів, якщо вони не відповідають екологічним та санітарно-гігієнічним вимогам;

- приймати рішення про розміщення і розвиток міст та інших населених пунктів без визначення технічних та інших заходів щодо створення умов для утилізації чи видалення побутових відходів;

- вводити в дію нові і реконструйовані підприємства та інші об'єкти, не забезпечені устаткуванням i технологіями для безпечного поводження з відходами, та в разі відсутності даних, необхідних для оцінки їх впливу на навколишнє природне середовище та здоров'я людини, згідно з установленим порядком;

- передавати чи продавати небезпечні відходи громадянам, підприємствам, установам та організаціям, якщо вони не забезпечують утилізації чи видалення цих відходів екологічно безпечним способом;

- залучати дітей і підлітків до організованого збирання відходів (як вторинної сировини), небезпечних для здоров'я;

- порушувати строки переробки відходів, ввезених в Україну відповідно до встановлених квотами умов; 
- порушувати встановлені квоти на ввезення в Україну відходів як вторинної сировини;

- ввезення в Україну, за винятком транзитного перевезення, будь-яких відходів з метою їх зберігання чи видалення;

- 31 січня 2018 року захоронення неперероблених (необроблених) побутових відходів.

Контроль у сфері поводження з відходами здійснюють центральний орган виконавчої влади, що реалізує державну політику із здійснення державного нагляду (контролю) у сфері охорони навколишнього природного середовища, раціонального використання, відтворення i охорони природних ресурсів, центральний орган виконавчої влади, що реалізує державну політику у сфері санітарного та епідемічного благополуччя населення, місцеві державні адміністрації, виконавчі органи сільських, селищних, міських рад, громадські інспектори з благоустрою населених пунктів.

В Україні здійснюються заходи щодо забезпечення утилізації відходів і зменшення обсягів їх утворення, зокрема:

- встановлення ставок екологічного податку, що справляється за розміщення відходів, із диференціацією залежно від рівня небезпеки відходів та цінності території;

- надання суб’єктам підприємницької діяльності, які утилізують, зменшують обсяги утворення відходів та впроваджують у виробництво маловідходні технології, відповідно до законодавства податкових, кредитних та інших пільг;

- надання в установленому законодавством порядку податкових, кредитних та інших пільг суб'єктам підприємницької діяльності, які здають відходи як вторинну сировину та займаються збиранням і заготівлею таких відходів;

- визначення пріоритетів щодо фінансування за державним контрактом підприємств, що впроваджують маловідходні технології, обробляють i утилізують відходи;

- перегляд переліку відходів, щодо яких 3 урахуванням державних інтересів повинен установлюватися спеціальний режим стимулювання їх збирання, заготівлі та використання;

- цільове фінансування науково-дослідних робіт з конкретних проблем утилізації відходів і зменшення їх утворення;

- створення фондів для цільового фінансування заходів щодо утилізації відходів за рахунок добровільних внесків виробників відходів, їх власників, вітчизняних та іноземних суб’єктів господарської діяльності, окремих громадян, екологічного страхування тощо;

- формування державного банку даних щодо впроваджених в Україні технологій утилізації відходів;

- стимулювання споживачів до роздільного збирання відходів шляхом виключення 3 плати за послугу поводження з побутовими відходами вартості операцій $з$ поводження 3 роздільно зібраними (відсортованими) корисними компонентами цих відходів.

3 метою стимулювання заходів щодо утилізації відходів та зменшення обсягів їх утворення суб'єктам господарської діяльності, які впроваджують технології, спрямовані на зменшення обсягів утворення відходів, утилізують відходи в процесі виробництва продукції (виконання робіт, надання послуг), 
здійснюють їх збирання і заготівлю, будівництво підприємств і цехів, а також організують виробництво устаткування для утилізації відходів, беруть пайову участь у фінансуванні заходів щодо утилізації відходів та зменшення обсягів їх утворення, можуть надаватися відповідно до закону України:

- пільги щодо оподаткування прибутку від реалізації продукції, виготовленої з використанням відходів;

- пріоритетне державне кредитування;

- спеціальні державні субсидії на зменшення відсотків за банківські кредити, пов'язані з інвестиціями, що спрямовуються на утилізацію відходів і виготовлення відповідного устаткування;

- дотації з Державного бюджету України і місцевих бюджетів для перевезення відходів (вторинної сировини) чи напівфабрикатів, одержаних 3 цих відходів;

- інформація щодо технологічних можливостей утилізації відходів;

- дотації з фондів охорони навколишнього природного середовища та інших джерел;

- пільги щодо поповнення обігових коштів підприємств, установ та організацій - суб'єктів господарської діяльності, що здійснюють збирання і заготівлю, оброблення (перероблення) і утилізацію відходів як вторинної сировини, за умови цільового використання цих коштів для придбання та переробки таких відходів.

Що стосується закордонного досвіду, керівні принципи ЄС у сфері охорони навколишнього середовища, зокрема, поводження із відходами, викладені в директивах: Рамкова Директива про відходи 2008/98/ЄС; Директива про небезпечні відходи 91/689/СС; Директива про всеохоплююче забруднення та його контроль 96/61/СС; Директива про спалювання відходів 2000/76/СС; Директива про захоронення відходів 1999/31/СС.

Рамкова Директива про відходи передбачає запровадження чіткої ієрархії пріоритетів поводження 3 відходами: 1) запобігання; 2) підготовка до повторного використання; 3) переробка; 4) інший тип утилізації, наприклад для відновлення енергії; 5) ліквідація (видалення на звалища).

Заходи із запобігання утворенню відходів мають на меті розірвати зв'язок між економічним зростанням та екологічними наслідками. Такими заходами $\epsilon$ економічні стимули (пільги, спеціальне оподаткування абощо), проведення освітніх кампаній. Сенс підготовки до повторного використання полягає у заходах, які продовжують життя тих чи інших речей та дозволяють використовувати таку річ більше одного разу після іiі виготовлення. Переробка таких відходів дозволяє економити сировину, зменшувати негативний вплив на довкілля як шляхом економії сировини, так і зменшення кількості відходів, які захоронюються на звалищах. Якщо переробка і компостування відходів $\epsilon$ недоцільними 3 технічних та економічних причин, в такому разі варто утилізувати сміття (в т.ч. шляхом відновлення енергії). Видалення (ліквідація) сміття на звалища - це останній спосіб поводження 3 відходами, і застосовуватися він має тоді, коли попередні способи вичерпано [30].

Директива вимагає встановити витрати таким чином, щоб відображати реальні природоохоронні витрати, пов'язані з утворенням та поводженням 3 відходами. Тому має бути також впроваджений принцип «забруднювач платить», що зобов'язує виробника та утримувача відходів поводитися 
з відходами таким чином, щоб гарантувати високий рівень захисту довкілля та здоров'я людини.

Одним 3 механізмів впровадження цього принципу $\epsilon$ розширена відповідальність виробника. Це означає, що виробник несе відповідальність за переробку та утилізацію своєї продукції після іiі споживання. Такий підхід запровадили на початку 1990-х років деякі країни теперішнього Європейського Союзу - Німеччина, Швеція, Франція. Згодом це було визнано як найкращий принцип та впроваджено на рівні ЄС. На сьогодні таким принципом керується більшість країн світу, його впроваджують також в Азії та Африці. Впровадження цієї моделі, зазвичай, має дві основні мети: перша полягає у збільшенні ставки збору і переробки вторинної сировини; друга в тому, щоб перекласти фінансову відповідальність з громадян та державних органів i тим самим стимулювати екологізацію виробів, зниження їх негативного впливу на довкілля.

Директива містить вимогу щодо складання Планів управління відходами та Програм запобігання утворенню відходів. Так, основою будь-якого управління має бути якісне планування. Плани мають покривати всю територію країни, вони поділяються на державні, регіональні і місцеві. Плани управління відходами мають бути спрямовані на досягнення сталого управління відходами, дотримання принципів управління відходами та містити чіткий аналіз потоків відходів і напрями управління ними, конкретні цілі.

Оскільки Європейський Союз надає велике значення саме запобіганню утворення відходів, в деяких країнах розробляються Програми запобігання утворенню відходів або ж питання запобігання утворенню відходів може бути включено до розділів Плану поводження з відходами. Програми із запобігання утворенню відходів повинні встановлювати цілі із запобігання утворенню відходів, мають містити опис існуючих заходів із запобігання утворенню відходів та запропонувати інші відповідні заходи, визначити відповідні кількісні чи якісні критерії для заходів із запобігання утворенню відходів, вжитих $з$ метою здійснення контролю та оцінки прогресу заходів, та можуть визначити конкретні якісні або кількісні цілі і показники.

Директива зобов'язує вжити заходів, щоб сприяти високій якості перероблення та 3 цією метою запровадити роздільне збирання відходів, принаймні для таких категорій відходів, як: папір, метал, пластик та скло.

Директива запроваджує Єдину в ЄС класифікацію відходів, в тому числі небезпечних, та вимагає вжити заходів, щоб виробництво, збирання, перевезення небезпечних відходів, так само як їх зберігання та оброблення, проводилися в умовах, що забезпечують захист довкілля та здоров'я людей, включаючи забезпечення можливості простежити від виробництва до кінцевого призначення i контролю небезпечних відходів. Забороняється змішування небезпечних відходів з іншими відходами, виключення можуть застосовуватись лише щодо визначених випадків. Під час збирання, перевезення та тимчасового зберігання небезпечні відходи мають бути спаковані та маркуватися відповідно до міжнародних стандартів та чинних стандартів Співтовариства. Коли небезпечні відходи переміщуються в межах держави-члена, вони повинні супроводжуватися ідентифікаційними документами, які можуть бути представлені в електронному вигляді та повинні містити належні дані, зазначені в Додатку IB до Регламенту (СС) № 1013/2006. 
Експлуатація підприємств, які займаються обробленням відходів, можлива лише на підставі дозволу. Такі дозволи мають містити види та кількість відходів, які можуть бути оброблені, для кожного з дозволених видів операцій технічні чи інші вимоги стосовно місця розташування, що розглядається, заходи безпеки, що слід застосувати, методи, що використовуються для кожного виду операцій, перевірка та контроль, що необхідно здійснювати тощо. Передумовою для отримання дозволу на спалювання або сумісне спалювання 3 утилізацією енергії, встановлена вимога, щоб відновлення енергії відбувалося на високому рівні енергоефективності. Якщо повноважний орган вважає, що запланований метод оброблення неприйнятний з точки зору захисту довкілля, він може відмовити у видачі дозволу. Установи чи підприємства, які проводять операції з оброблення відходів, установи чи підприємства, які збирають або перевозять відходи на професійній основі, установи чи підприємства, які продукують небезпечні відходи, повинні проходити належну періодичну перевірку, що проводять повноважні органи.

Таким чином, за результатами дослідження виявлено, що поводження 3 відходами, у тому числі харчовими, в Україні регламентується низкою законів, зокрема законом «Про відходи», який встановлює правові, організаційні та економічні засади діяльності, пов'язаної із запобіганням або зменшенням обсягів утворення відходів, їх збиранням, перевезенням, зберіганням, сортуванням, обробленням, утилізацією та видаленням, знешкодженням та захороненням, а також з відверненням негативного впливу відходів на навколишнє природне середовище та здоров'я людини на території України. Основою регламентації поводження з відходами в країнах ЄС є низка директив, основною з яких є Директива № 2008/98/СС про відходи (Рамкова директива про відходи), основною метою якої $є$ встановлення системи управління відходами, що максимально зменшить негативний вплив на здоров'я людини та довкілля й забезпечить збереження природних ресурсів, а також чітко регламентує питання утворення та поводження із відходами. Імплементація європейського законодавства, а також формування ієрархії пріоритетів поводження 3 відходами: запобігання, підготовка до повторного використання, переробка, інший тип утилізації, ліквідація, - є напрямом євроінтеграції України.

\section{Висновки}

За результатами дослідження констатована відсутність визначеного поняття харчових відходів в українському законодавстві, що утруднює ефективне управління відходами. Запропоновано введення до вжитку поняття «втрата продовольства та харчові відходи» («Food loss and waste»), яке використовується, зокрема, Продовольчою та сільськогосподарською організацією ООН (FAO). Наголошено на необхідності імплементації європейського законодавства, зокрема Рамкової директиви про відходи, та формування п’ятирівневої ієрархії пріоритетів поводження з відходами як напряму євроінтеграції України.

Напрямами подальшого дослідження виступатиме вивчення технологій утилізації харчових відходів сучасного міста. 


\section{СПИСОК ЛІТЕРАТУРИ}

1. Корнякова Н.О. Поняття відходів за законодавством України та Європейського Союзу: порівняльно-правовий аналіз. Право України. 2004. № 5. С. 149-153.

2. Трусов А.Д., Захаров А.Н. Комплексное использование сырьевых ресурсов: пути повышения экономической эффективности в условиях НТП. М.: Экономика, 1986. $110 \mathrm{c}$.

3. Дериколенко О.М., Кержаков В.І. Економіка використання вторинних матеріальних ресурсів. К.: 1986. 224 с.

4. Пилипів Н.І., Максимів Ю.В. Економічна сутність та класифікація відходів для відображення їх в обліку на деревообробних підприємствах. Вісник ЖДТУ. № 3 (53). 2010. C. 201-205.

5. Про відходи: Закон України від 05.03.1998 p. № 187/98 - BP. URL: https://zakon.rada.gov.ua/laws/show/187/98-\%D0\%B2\%D1\%80\#Text.

6. Про альтернативні види рідкого та газового палива: Закон України від 14.01 .2000 p.

№ 187/98 - BP. URL: https://zakon.rada.gov.ua/laws/show/1391-14\#Text.

7. Класифікатор відходів ДК 005-96: наказ Держстандарту України від 29.02.1996 р. № 89. URL: https://zakon.rada.gov.ua/rada/show/v0089217-96\#Text.

8. ДСТУ 2195-99 «Охорона природи. Поводження з відходами. Технічний паспорт відходу»: наказ Держстандарту України від 08.09.1999 p. № 167. URL: http://online.budstandart.com/ua/catalog/doc-page?id_doc=51481.

9. Методика обстеження й паспортизації гідротехнічних споруд систем гідравлічного вилучення та складування промислових відходів: Наказ Держкоммістобудування від 19.12.1995 p. № 252. URL: https://zakon.rada.gov.ua/laws/show/z0466-95\#Text.

10. Пікінер B.В. Поняття “відходи”: правовий, економічний та обліковий підходи. URL: http://eztuir.ztu.edu.ua/bitstream/handle/123456789/3014/45.pdf?sequence=1\&isAllowed=y.

11. Пендак В., Паславська О.Я. Побутові відходи - загроза екологічної безпеки людства. URL: http://dspace.wunu.edu.ua/bitstream/316497/19836/1/73-76.pdf.

12. Довга Т.М. Класифікація побутових відходів як передумова ефективності їх рециклінгу в Україні. Економічний часопис-XXI. 2011. № 5-6. С. 50-53.

13. Lipinski B., Hanson C., Lomax J., Kitinoja L., Waite R., Searchinger T. Reducing food loss and waste. Working paper, installment 2 of «Creating a sustainable food future». Washington: World resources institute, 2013. 40 p. URL: https://files.wri.org/s3fspublic/reducing_food_loss_and_waste.pdf.

14. Global food losses and food waste - extent, causes and prevention. Rome: FAO, 2011. 37 p. URL: http://www.fao.org/docrep/014/mb060e/mb060e00.pdf.

15. Global initiative on food loss and waste reduction. Rome: FAO, 2015. 8 p. URL: http://www.fao.org/3/a-i4068e.pdf.

16. Hanson C., Mitchell P. The business case for reducing food loss and waste. A report on behalf of Champions 12.3. 2017. URL: http://www.wrap.org.uk/sites/files/wrap/Report_ The $\% 20$ Business $\% 20$ Case $\% 20$ for $\% 20$ Reducing $\% 20$ Food $\% 20$ Loss $\% 20$ and $\% 20$ Waste.pdf. 17. Richards T. J., Hamilton S. F. Food waste in the sharing economy. Food Policy. 2018. Vol. 75. Pp. 109-123. https://doi.org/10.1016/j.foodpol.2018.01.008.

18. Mylona K., Maragkoudakis P., Miko L., Bock A.-K., Wollgast J., Caldeira S., Ulberth F. Future of food safety and nutrition - seeking win-wins, coping with trade-offs. Food Policy. 2018. Vol. 74. Pp. 143-146. https://doi.org/10.1016/j.foodpol.2017.12.002.

19. Zezza A., Carletto C., Fiedler J. L., Gennari P., Jolliffe D. Food counts. Measuring food consumption and expenditures in household consumption and expenditure surveys (HCES). Introduction to the special issue. Food Policy. 2017. Vol. 72. Pp. 1-6. https://doi.org/10.1016/j.foodpol.2017.08.007.

20. Котикова О., Бабич М., Погорєлова О. Втрати продовольства та харчові відходи в ланцюзі створення вартості продовольства в Україні. Agricultural and Resource Economics: International Scientific E-Journal. 2020. Vol. 6. No. 3. C. 191-220. 
21. Про забезпечення санітарного та епідемічного благополуччя населення: Закон України від 24.02.1994 р. № 4004-XII. URL: https://zakon.rada.gov.ua/laws/show/400412\#Text.

22. Про охорону навколишнього природного середовища: Закон України від 25.06.1991 p. № 1264-XII. URL: https://zakon.rada.gov.ua/laws/show/1264-12\#Text.

23. Про поводження 3 радіоактивними відходами: Закон України від 30.06 .1995 р. № 255/95-BP. URL: https://zakon.rada.gov.ua/laws/show/255/95-\%D0\%B2\%D1\%80\#Text.

24. Про металобрухт: Закон України від 05.05.1999 p. № 619-XIV. URL: https://zakon.rada.gov.ua/laws/show/619-14\#Text.

25. Про житлово-комунальні послуги: Закон України від 09.11.2017 р. № 2189-VIII. URL: https://zakon.rada.gov.ua/laws/show/2189-19\#Text.

26. Про хімічні джерела струму: Закон України від 23.02.2006 p. № 3503-IV. URL: https://zakon.rada.gov.ua/laws/show/3503-15\#Text.

27. Про ветеринарну медицину: Закон України від 25.06.1992 p. № 2498-XII. URL: https://zakon.rada.gov.ua/laws/show/2498-12\#Text.

28. Про вилучення 3 обігу, переробку, утилізацію, знищення або подальше використання неякісної та небезпечної продукції: Закон України від 14.01.2000 p. № 1393-XIV. URL: https://zakon.rada.gov.ua/laws/show/1393-14\#Text.

29. Кодекс України про надра від 27.07.1994 p. № 132/94-BP URL: https://zakon.rada.gov.ua/laws/show/132/94-\%D0\%B2\%D1\%80\#Text.

30. Директива № 2008/98/ЄC про відходи (Рамкова директива про відходи). URL: http://epl.org.ua/wp-content/uploads/2019/09/Ramkova-dyrektyva-presreliz.pdf.

Стаття надійшла до редакиї 12.03.2021 і прийнята до друку після рецензування 30.06 .2021

\section{REFERENCES}

1. Korniakova, N.O. (2004). Poniattia vidkhodiv za zakonodavstvom Ukrainy ta Yevropeiskoho Soiuzu: porivnialno-pravovyi analiz. Pravo Ukrainy, 5, 149-153 [in Ukrainian].

2. Trusov, A.D., \& Zakharov, A.N. (1986). Kompleksnoye ispolzovaniye syryevykh resursov: puti povysheniya ekonomicheskoy effektivnosti v usloviyakh NTP. Moscow: Ekonomika [in Russian].

3. Derykolenko, O.M., \& Kerzhakov, V.I. (1986). Ekonomika vykorystannia vtorynnykh materialnykh resursiv. Kyiv [in Ukrainian].

4. Pylypiv, N.I., \& Maksymiv, Yu.V. (2010). Ekonomichna sutnist ta klasyfikatsiia vidkhodiv dlia vidobrazhennia yikh v obliku na derevoobrobnykh pidpryiemstvakh. Visnyk ZhDTU, 3 (53), 201-205 [in Ukrainian].

5. Pro vidkhody: Zakon Ukrainy vid 05.03.1998. № 187/98 - VR. Retrieved from: https://zakon.rada.gov.ua/laws/show/187/98-\%D0\%B2\%D1\%80\#Text [in Ukrainian].

6. Pro alternatyvni vydy ridkoho ta hazovoho palyva: Zakon Ukrainy vid 14.01.2000. № 187/98 - VR. Retrieved from: https://zakon.rada.gov.ua/laws/show/1391-14\#Text [in Ukrainian].

7. Klasyfikator vidkhodiv DK 005-96: nakaz Derzhstandartu Ukrainy vid 29.02.1996. № 89. Retrieved from: https://zakon.rada.gov.ua/rada/show/v0089217-96\#Text [in Ukrainian].

8. DSTU 2195-99 «Okhorona pryrody. Povodzhennia z vidkhodamy. Tekhnichnyi pasport vidkhodu»: nakaz Derzhstandartu Ukrainy vid 08.09.1999. № 167. Retrieved from: http://online.budstandart.com/ua/catalog/doc-page?id_doc=51481 [in Ukrainian].

9. Metodyka obstezhennia y pasportyzatsii hidrotekhnichnykh sporud system hidravlichnoho vyluchennia ta skladuvannia promyslovykh vidkhodiv: Nakaz Derzhkommistobuduvannia vid 19.12.1995 № 252. Retrieved from: https://zakon.rada.gov.ua/laws/show/z0466-95\#Text [in Ukrainian]. 
10. Pikiner, V.V. (n.d.). Poniattia "vidkhody": pravovyi, ekonomichnyi ta oblikovyi pidkhody. Retrieved from: http://eztuir.ztu.edu.ua/bitstream/handle/123456789/3014/45. pdf?sequence $=1 \&$ isAllowed $=y$ [in Ukrainian].

11. Pendak, V., \& Paslavska, O.Ia. (n.d.). Pobutovi vidkhody - zahroza ekolohichnoi bezpeky liudstva. Retrieved from: http://dspace.wunu.edu.ua/bitstream/316497/19836/1/73-76.pdf [in Ukrainian].

12. Dovha, T.M. (2011). Klasyfikatsiia pobutovykh vidkhodiv yak peredumova efektyvnosti yikh retsyklinhu v Ukraini. Ekonomichnyi chasopys-KhKhI, 5-6, 50-53 [in Ukrainian].

13. Lipinski, B., Hanson, C., Lomax, J., Kitinoja, L., Waite, R., \& Searchinger, T. (2013). Reducing food loss and waste. Working paper, installment 2 of "Creating a sustainable food future». Washington: World resources institute. Retrieved from: https://files.wri.org/s3fspublic/reducing_food_loss_and_waste.pdf.

14. Global food losses and food waste - extent, causes and prevention (2011). Rome: FAO. Retrieved from: http://www.fao.org/docrep/014/mb060e/mb060e00.pdf.

15. Global initiative on food loss and waste reduction (2015). Rome: FAO. Retrieved from: http://www.fao.org/3/a-i4068e.pdf.

16. Hanson, C., \& Mitchell, P. (2017). The business case for reducing food loss and waste. A report on behalf of Champions 12.3. Retrieved from: http://www.wrap.org.uk/ sites/files/wrap/Report_The $\% 20$ Business $\% 20$ Case $\% 20$ for\%20Reducing\%20Food\%20Loss $\% 20$ and \%20Waste.pdf.

17. Richards, T.J., Hamilton, S.F. (2018). Food waste in the sharing economy. Food Policy, 75, 109-123. https://doi.org/10.1016/j.foodpol.2018.01.008.

18. Mylona, K., Maragkoudakis, P., Miko, L., Bock, A.-K., Wollgast, J., Caldeira, S., \& Ulberth, F. (2018). Future of food safety and nutrition - seeking win-wins, coping with tradeoffs. Food Policy, 74, 143-146. https://doi.org/10.1016/j.foodpol.2017.12.002.

19. Zezza, A., Carletto, C., Fiedler, J. L., Gennari, P., \& Jolliffe, D. (2017). Food counts. Measuring food consumption and expenditures in household consumption and expenditure surveys (HCES). Introduction to the special issue. Food Policy, 72, 1-6. https://doi.org/10.1016/j.foodpol.2017.08.007.

20. Kotykova, O., Babych, M., \& Pohorielova, O. (2020). Vtraty prodovolstva ta kharchovi vidkhody v lantsiuzi stvorennia vartosti prodovolstva v Ukraini. Agricultural and Resource Economics: International Scientific E-Journal, 3, 191-220 [in Ukrainian].

21. Pro zabezpechennia sanitarnoho ta epidemichnoho blahopoluchchia naselennia: Zakon Ukrainy vid 24.02.1994. № 4004-XII. Retrieved from: https://zakon.rada.gov.ua/laws/show/4004-12\#Text [in Ukrainian].

22. Pro okhoronu navkolyshnoho pryrodnoho seredovyshcha: Zakon Ukrainy vid 25.06.1991. № 1264-XII. Retrieved from: https://zakon.rada.gov.ua/laws/show/126412\#Text [in Ukrainian].

23. Pro povodzhennia z radioaktyvnymy vidkhodamy: Zakon Ukrainy vid 30.06.1995. № 255/95-VR. Retrieved from: https://zakon.rada.gov.ua/laws/show/255/95$\% \mathrm{D} 0 \% \mathrm{~B} 2 \% \mathrm{D} 1 \% 80 \#$ Text [in Ukrainian].

24. Pro metalobrukht: Zakon Ukrainy vid 05.05.1999. № 619-XIV. Retrieved from: https://zakon.rada.gov.ua/laws/show/619-14\#Text [in Ukrainian].

25. Pro zhytlovo-komunalni posluhy: Zakon Ukrainy vid 09.11.2017. № 2189-VIII. Retrieved from: https://zakon.rada.gov.ua/laws/show/2189-19\#Text [in Ukrainian].

26. Pro khimichni dzherela strumu: Zakon Ukrainy vid 23.02.2006. № 3503-IV. Retrieved from: https://zakon.rada.gov.ua/laws/show/3503-15\#Text [in Ukrainian].

27. Pro veterynarnu medytsynu: Zakon Ukrainy vid 25.06.1992. № 2498-XII. Retrieved from: https://zakon.rada.gov.ua/laws/show/2498-12\#Text [in Ukrainian].

28. Pro vyluchennia $\mathrm{z}$ obihu, pererobku, utylizatsiiu, znyshchennia abo podalshe vykorystannia neiakisnoi ta nebezpechnoi produktsii: Zakon Ukrainy vid 14.01.2000. № 1393-XIV. Retrieved from: https://zakon.rada.gov.ua/laws/show/1393-14\#Text [in Ukrainian]. 
29. Kodeks Ukrainy pro nadra vid 27.07.1994. № 132/94-VR Retrieved from: https://zakon.rada.gov.ua/laws/show/132/94-\%D0\%B2\%D1\%80\#Text [in Ukrainian].

30. Dyrektyva № 2008/98/ES pro vidkhody (Ramkova dyrektyva pro vidkhody). Retrieved from: http://epl.org.ua/wp-content/uploads/2019/09/Ramkova-dyrektyva-presreliz.pdf [in Ukrainian].

The article was received 12.03.2021 and was accepted after revision 30.06.2021

\section{Міхсєнко Вікторія Михайлівна}

кандидат хімічних наук, доцент кафедри прикладної екології, хімії і охорони праці Донбаської національної академії будівництва і архітектури

Адреса робоча: 84333 Україна, м. Краматорськ, вул. Героїв Небесної Сотні, 14 ORCID ID 0000-0001-7685-2507 e-mail: v.m.mikheenko@donnaba.edu.ua

\section{Гевлич Іван Геннадійович}

кандидат технічних наук, доцент кафедри теплогазоводопостачання, водовідведення та вентиляції Донбаської національної академії будівництва і архітектури

Адреса робоча: 84333 Україна, м. Краматорськ, вул. Героїв Небесної Сотні, 14 ORCID ID 0000-0003-2282-0512 e-mail: i.g.gevlich@donnaba.edu.ua

\section{Гевлич Тарас Іванович}

бакалавр за ОП «Екологія та охорона навколишнього середовища» Донбаської національної академії будівництва і архітектури

Адреса робоча: 84333 Україна, м. Краматорськ, вул. Героїв Небесної Сотні, 14 ORCID ID 0000-0003-3387-1657 e-mail: t.gevlich@donnaba.edu.ua 